\title{
Therapeutic Potential of Allicin-Rich Garlic Preparations: Emphasis on Clinical Evidence toward Upcoming Drugs Formulation
}

\author{
Javad Sharifi-Rad ${ }^{1, *(\mathbb{D}}$, Nathália Cristina Cirone Silva ${ }^{2}{ }^{(0}$, Arvind Jantwal ${ }^{3} \mathbb{D}$, Indra D. Bhatt ${ }^{4, *}$, \\ Farukh Sharopov ${ }^{5, *(D)}$, William C. Cho ${ }^{6, *(D)}$, Yasaman Taheri ${ }^{7}$ (D) and Natália Martins ${ }^{8,9, *(D)}$ \\ 1 Zabol Medicinal Plants Research Center, Zabol University of Medical Sciences, Zabol 61615-585, Iran \\ 2 Department of Food Science, Faculty of Food Engineering (FEA), University of Campinas (UNICAMP), \\ Campinas, 13083-862 Sao Paulo, Brazil; ncirone@unicamp.br \\ 3 Department of Pharmaceutical Sciences, Bhimtal Campus, Kumaun University, Nainital 263136, \\ Uttarakhand, India; arvind.jantwal@gmail.com \\ 4 G.B. Pant National Institute of Himalayan Environment and Sustainable Development, Kosi Katarmal, \\ Almora 263643, India \\ 5 Research Institution "Chinese-Tajik Innovation Center for Natural Products", Academy of Sciences of the \\ Republic of Tajikistan, Ayni 299/2, Dushanbe 734063, Tajikistan \\ 6 Department of Clinical Oncology, Queen Elizabeth Hospital, 30 Gascoigne Road, Hong Kong, China \\ 7 Department of Pharmacology and Toxicology, School of Pharmacy, Shahid Beheshti University of Medical \\ Sciences, Tehran 11369, Iran; taaheri.yasaman@gmail.com \\ 8 Faculty of Medicine, University of Porto, Alameda Prof. Hernâni Monteiro, 4200-319 Porto, Portugal \\ 9 Institute for Research and Innovation in Health (i3S), University of Porto, 4200-135 Porto, Portugal \\ * Correspondence: javad.sharifirad@gmail.com (J.S.-R.); idbhatt@gbpihed.nic.in (I.D.B.); \\ shfarukh@mail.ru (F.S.); chocs@ha.org.hk (W.C.C.); ncmartins@med.up.pt (N.M.)
}

Received: 1 November 2019; Accepted: 5 December 2019; Published: 17 December 2019

\begin{abstract}
Garlic has been used for a long time in human history. Allicin, the main active compound present in freshly injured garlic, is enzymatically formed from alliin. Allicin has shown doubtless beneficial effects and even be conceived as medicine. The present review highlights allicin-associated studies. Indeed, clinical studies on healthy subjects have evidenced that standardized garlic treatment (900 mg/day) significantly reduces total cholesterol (TC) and low-density lipoprotein cholesterol (c-LDL). Besides, allicin also led to a marked improvement in mouth opening, burning sensation, and oral health-related quality of life on stage II oral submucous fibrosis patients. Interestingly, in children, allicin also has been proposed for thrush prevention and as an alternative antibiotic therapy. Nonetheless, there is particular attention to allicin bioavailability, given its high instability. Although clinical evidence has promoted allicin release from garlic powder tablets under simulated gastrointestinal conditions, garlic tablets are those that have provided less alliinase protection due to its fast disintegration, releasing low allicin amounts.
\end{abstract}

Keywords: Allium sativum L.; allicin; garlic preparations; cholesterol

\section{Introduction}

Plants have been used since the beginning of human civilization [1,2]. Some of them are able to provide remarkable biological effects [3-8] to treat several illnesses, such as psychiatric (anxiety and depression) [9] and cardiovascular disorders (acting as a vasorelaxant, and exerting direct positive effects on cardiac hypertrophy, angiogenesis, platelet aggregation, hyperlipidemia and hyperglycemia) [10], cancer [11-13], and even conferring a pronounced antimicrobial activity [14]. 
Garlic (Allium sativum L.) and other Allium species are popular due to its characteristic odor and folk medicinal uses, and recent studies have provided in-depth insights on garlic effects as a medicinal plant $[15,16]$. A. sativum is a member of the Alliaceae family, worldwide cultivated and selected as a valuable spice [17]. Garlic contains many substances, among them sulfur compounds (such as allicin, aliin, ajoene, allyl propyl disulfide, diallyl trisulfide, S-Allyl cysteine, vinyldithiines, S-allylmercaptocystein, among others), which also are produced by many other Allium species. Allicin $\left(\mathrm{C}_{6} \mathrm{H}_{10} \mathrm{OS}_{2}\right)$ is a volatile compound present in garlic and other Allium species, like an onion (Allium cepa L.) [10]. Alliin (L-(+)-S-Allyl cystein sulfoxide) is an amino acid which, under the action of the alliinase enzyme, converts to allyl sulfenic acid (2-propenesulfenic acid) [18], an unstable and highly reactive compound at room temperature. Then, two allyl sulfenic acid molecules condense spontaneously, forming allicin with consequent water elimination (Figure 1). Multiple studies have focused on allicin therapeutic potential as an antioxidant (inducing antioxidant product production), anticancer (triggering cancer cells apoptosis and inhibiting tumor growth), antimicrobial (inhibiting toxin production and microbial activity), antifibrotic (decreasing tumor necrosis factor-alpha protein activity) and cardioprotective (decreasing angiogenesis and inducing vasorelaxation) [10,17-20]. Based on these remarkable biological effects, garlic has been increasingly exploited toward an alternative treatment for many diseases $[10,15,16]$. Thus, clinical evidence has increased to validate this compound as a promising drug for effective and safer therapeutic applications $[19,21]$. This paper aims to provide the scientific evidence on allicin-rich garlic preparations' pharmacological effects.<smiles>C=CCS(=O)CC(N)C(=O)O</smiles>

Alliin

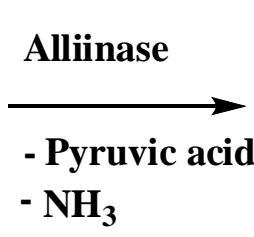

Alliinase

$-\mathrm{NH}_{3}$<smiles>C=CCSO</smiles>

Allyl sulfenic acid<smiles>C=CCSO</smiles>

Allyl sulfenic acid<smiles>C=CCS(=O)CC=C</smiles>

Allicin

Figure 1. Allicin chemical structure and its formation.

\section{Drifting from Molecular to Clinical Evidence}

Garlic has been widely used for its cholesterol-lowering effects historically, but studies focusing on its efficacy and effectiveness has failed to prove it [22]. Additionally, in some cases, the quality of allicin-containing products is questionable, given the sources of garlic used, the preparation method.

\subsection{Cardioprotective Activity}

\subsubsection{Atherosclerosis}

There are several randomized, double-blinded, and placebo-controlled clinical trials assessing the anti-atherosclerotic activity of allicin-containing products (Table 1), such as garlic powder tablets, capsules containing AGE (aged garlic extract) and even the Allicor garlic-based drug. 
Table 1. Clinical trials assessing cardioprotective effects of allicin or allicin containing products/formulations

\begin{tabular}{|c|c|c|c|c|c|}
\hline Clinical Trial & Participants & Duration & Dose & Summary & References \\
\hline \multicolumn{6}{|c|}{ Atherosclerosis } \\
\hline $\mathrm{R}, \mathrm{DB}, \mathrm{PC}$ & 152 individuals & 48 months & High-dose garlic powder & $\begin{array}{l}\text { Plaque volume in the whole collective remained practically constant within the age-span of } 50-80 \\
\text { years, substantiating not only a garlic preventive but possibly a curative role in arteriosclerosis } \\
\text { (plaque regression) }\end{array}$ & [23] \\
\hline $\mathrm{R}, \mathrm{DB}, \mathrm{PC}$ & 65 individuals & 12 months & $\begin{array}{l}\text { Capsule containing aged garlic extract } \\
(250 \mathrm{mg}) \text { plus Vitamins B12 (100 } \mu \mathrm{g}), \mathrm{B} 9(300 \\
\mu \mathrm{g}), \mathrm{B} 6(12.5 \mathrm{mg}) \text { and L-arginine }(100 \mathrm{mg})\end{array}$ & $\begin{array}{l}\text { Aged garlic extract supplemented with sulphur was associated with a favorable improvement in } \\
\text { oxidative biomarkers, vascular function, and reduced atherosclerosis progression }\end{array}$ & [24] \\
\hline $\mathrm{R}, \mathrm{DB}, \mathrm{PC}$ & 196 asymptomatic men & & $\begin{array}{l}\text { Garlic-based drug Allicor (INAT-Pharma, } \\
\text { Moscow, Russia) ( } 300 \mathrm{mg} / \text { day) }\end{array}$ & $\begin{array}{l}\text { 2-year treatment with Allicor had a direct anti-atherosclerotic effect on carotid atherosclerosis in } \\
\text { asymptomatic men }\end{array}$ & [25] \\
\hline $\mathrm{R}$ & 65 firefighters & & $\begin{array}{l}\text { Aged garlic extract (300 mg/tablet) plus } \\
\text { CoQ10 (30 mg/tablet) }\end{array}$ & $\begin{array}{l}\text { This combination was independently associated with significant beneficial effects on vascular } \\
\text { elasticity and endothelial function in firefighters with high occupational stress, highlighting the } \\
\text { important role of these substances in atherosclerotic prevention }\end{array}$ & [26] \\
\hline \multicolumn{6}{|c|}{ Hypertension } \\
\hline \multirow[t]{2}{*}{$\mathrm{R}$} & 50 individuals & 12 weeks & $\begin{array}{l}\text { Aged garlic extract ( } 960 \mathrm{mg} \text { containing } \\
2.4 \mathrm{mg} \text { S-Allyl cysteine) }\end{array}$ & $\begin{array}{l}\text { Aged garlic extract effect was superior to placebo in lowering systolic blood pressure (similar to } \\
\text { current first line medications) in patients with treated but uncontrolled hypertension }\end{array}$ & [27] \\
\hline & $84 \mathrm{men}$ & 8 weeks & 900 mg Kwai (garlic pills) & It was effective in the treatment of mild and moderate arterial hypertension & [28] \\
\hline $\mathrm{R}, \mathrm{DB}, \mathrm{PC}$ & 80 individuals & 8 weeks & $800 \mathrm{mg}$ garlic powder & $\begin{array}{l}\text { Increased walking distance and decreased diastolic blood pressure, spontaneous thrombocyte } \\
\text { aggregation, plasma viscosity, and cholesterol levels }\end{array}$ & [29] \\
\hline DB & 42 healthy adults & 12 weeks & $900 \mathrm{mg}$ standardized garlic powder & $\begin{array}{l}\text { No significant changes in serum HDL-c, triglycerides, blood pressure and glucose levels. Garlic } \\
\text { seemed to be mostly effective in reducing LDL-c levels }\end{array}$ & [30] \\
\hline \multicolumn{6}{|l|}{ Hyperlipidemia } \\
\hline $\mathrm{R}, \mathrm{DB}, \mathrm{PC}$ & 30 individuals & 12 weeks & Kwai@ garlic powder tablets 900 mg/daily & $\begin{array}{l}\text { There was no demonstrable effect of garlic on LDL oxidation, plasma lathosterol-I-cholestero1 ratio, } \\
\text { nor on LDL receptor expression in lymphocytes }\end{array}$ & [31] \\
\hline Meta-analysis & - & & - & No significant effect of garlic supplementation on Lp (a) levels reduction & [32] \\
\hline $\mathrm{R}, \mathrm{DB}, \mathrm{PC}$ & 40 individuals & 4 months & $900 \mathrm{mg}$ garlic powder & Significantly lowered total cholesterol, triglycerides and blood pressure & [33] \\
\hline $\mathrm{R}, \mathrm{DB}, \mathrm{PC}$ & 50 individuals & 12 weeks & $900 \mathrm{mg}$ tablet garlic extract & $\begin{array}{l}\text { Garlic had no effect on major plasma lipoproteins, and it has no impact on HDL-c subclasses, Lp (a), } \\
\text { apolipoprotein B, postprandial triglycerides or LDL-c subclass distribution }\end{array}$ & [34] \\
\hline $\mathrm{R}, \mathrm{DB}, \mathrm{PC}$ & 30 pediatric patients, aged $8-18$ years & 8 weeks & $900 \mathrm{mg}$ garlic extract & No significant effect on cardiovascular risk factors in pediatric patients with familial hyperlipidemia & [35] \\
\hline $\mathrm{R}, \mathrm{DB}, \mathrm{PC}$ & 2 out-patient lipid clinics & 12 weeks & $900 \mathrm{mg}$ garlic powder & Ineffective in lowering cholesterol levels in patients & [36] \\
\hline $\mathrm{R}, \mathrm{DB}, \mathrm{PC}$ & 52 out-patients & 6 months & $\begin{array}{l}900 \mathrm{mg} \text { garlic powder tablet (Kwai) } \\
\text { (standardized to } 1.3 \% \text { alliin) }\end{array}$ & Mean values for LDL-C were reduced by nearly $10 \%$ by garlic and $6 \%$ by placebo & [37] \\
\hline$R, D B, P C$ & 68 normal volunteers & 15 weeks & $\begin{array}{l}600 \mathrm{mg} \text { dried garlic powder (standardized } \\
\text { on } 1.3 \% \text { allicin) }\end{array}$ & $\begin{array}{l}\text { Total cholesterol dropped from } 223 \text { to } 214 \mathrm{mg} / \mathrm{dl} \text {, triglycerides decreased from } 124 \text { to } 118 \mathrm{mg} / \mathrm{dl} \text {, and } \\
\text { blood pressure remained constant }\end{array}$ & [38] \\
\hline$R, D B, P C$ & 42 healthy adults & & $900 \mathrm{mg}$ standardized garlic powder & Greater reduction in serum total cholesterol LDL-c & [30] \\
\hline
\end{tabular}


Table 1. Cont.

\begin{tabular}{|c|c|c|c|c|c|}
\hline Clinical Trial & Participants & Duration & Dose & Summary & References \\
\hline open-label study & 50 individuals & 90 days & $3 \mathrm{~g}$ of raw garlic daily & $\begin{array}{l}\text { Garlic has a role in cholesterol management as adjunctive therapy in most cases of significant } \\
\text { hypercholesterolemia, reducing the risk of atherosclerosis and cardiovascular events }\end{array}$ & [39] \\
\hline $\mathrm{R}, \mathrm{DB}, \mathrm{PC}$ & 51 adults & 12 weeks & 500 or 1000 mg dehydrated garlic powder & $\begin{array}{l}\text { No significant effect on plasma lipids levels and therefore, there was no indication of a graded effect } \\
\text { by garlic dose over } 0,500 \text { and } 1000 \mathrm{mg} / \text { day }\end{array}$ & [40] \\
\hline \multirow[t]{3}{*}{$\mathrm{DB}, \mathrm{R}, \mathrm{PC}$} & 31 individuals & 26 weeks & $\begin{array}{l}900 \mathrm{mg} \mathrm{Kwai} \mathrm{garlic} \mathrm{(standardized} \mathrm{to} 0.6 \% \\
\text { allicin, } 1.3 \% \text { alliin) }\end{array}$ & $\begin{array}{c}\text { Antibody levels to oxidized LDL were unchanged, and lipoprotein(a) levels in plasma also were not } \\
\text { changed }\end{array}$ & [41] \\
\hline & 98 individuals & & $\begin{array}{l}900 \mathrm{mg} \text { of garlic powder (standardized as to } \\
1.3 \% \text { alliin) }\end{array}$ & Significant reduction in total cholesterol, LDL-c, and triglycerides, and an increase in HDL-c & [42] \\
\hline & 20 individuals & 4 weeks & $600 \mathrm{mg}$ dried garlic & $\begin{array}{l}\text { Significant decrease in fibrinogen and fibrinopeptide } A \text { and increase in streptokinase-activated } \\
\text { plasminogen and fibrinopeptide B beta } 15-42 \text { coagulation factor. The decrease in Serum cholesterol } \\
\text { levels, Systolic, and diastolic blood pressure }\end{array}$ & [43] \\
\hline \multicolumn{6}{|l|}{ Obesity } \\
\hline $\mathrm{DB}, \mathrm{R}, \mathrm{PC}$ & 110 individuals & & $800 \mathrm{mg}$ garlic powder & Significant reductions were observed in body weight and body fat mass $(P<0.05)$ & [44] \\
\hline $\mathrm{R}, \mathrm{DB}, \mathrm{PC}$ & 75 individuals & 12 weeks & $\begin{array}{l}\text { Dried garlic powder tablets }(10.8 \mathrm{mg} \text { alliin } \\
\quad \text { (3-(2-propenylsulfinyl)-L-alanine) }\end{array}$ & $\begin{array}{l}\text { No clinically relevant lipid-lowering and blood pressure-lowering effects in middle-aged, } \\
\text { normolipidemic individuals. The putative anti-atherosclerotic effect of garlic may be linked to risk } \\
\text { markers other than blood lipids }\end{array}$ & [45] \\
\hline
\end{tabular}

DB, double-blinded; PC, placebo-controlled; R, randomized 
Aged garlic extract supplementation with B vitamins, folic acid and L-arginine has been associated with the progression of subclinical atherosclerosis [24]. A two-year treatment with Allicor (garlic powder) exerted a direct anti-atherosclerotic effect on carotid atherosclerosis in asymptomatic men [25]. Also, the age-dependent representation of the plaque volume shows an increase between 50 and 80 years that is diminished under garlic treatment by $6-13 \%$ over 4 years. It seems important that through garlic application, the plaque volume in the whole collective remained practically constant within the age-span of 50-80 years. These results have shown that not only preventive but also therapeutic benefits in arteriosclerosis therapy (plaque regression) may be ascribed to garlic remedies [23]. Additionally, the combination of aged garlic extract and $\mathrm{CoQ}_{10}$ was independently associated with pronounced beneficial effects on vascular elasticity and endothelial function in firefighters with high occupational stress, highlighting the crucial role of both $\mathrm{AGE}$ and $\mathrm{CoQ}_{10}$ (Coenzyme $\mathrm{Q}_{10}$ ) in atherosclerosis prevention of such individuals [26].

\subsubsection{Hyperlipidemia and Hypertension}

Multiple clinical trials have been performed to assess the effects of garlic and its derived products on hyperlipidemia and hypertension (Table 1). A 12-week double-blind study was carried out to compare standard garlic powder tablet and placebo effects on serum lipids, lipoproteins, blood pressure, and glucose levels. During that study, 42 healthy adults (19 men, 23 women, mean age of $52 \pm 12$ years) were enrolled, whose serum total cholesterol (TC) was greater than or equal to $220 \mathrm{mg} / \mathrm{dL}$ [30]. All the subjects received, either standardized garlic powder in form of a tablet (dose $300 \mathrm{mg}, 3$ times/day) or a placebo, in a randomized, double-blind study design. Daily diets and physical activity were unchanged. After 12 weeks, the obtained data clearly showed a decrease in TC ( $262 \pm 34 \mathrm{mg} / \mathrm{dL}$ to $247 \pm 40 \mathrm{mg} / \mathrm{dL}$ ) in the group receiving the standardized garlic powder tablet, when compared to the placebo group ( $276 \pm 34 \mathrm{mg} / \mathrm{dL}$ to $274 \pm 29 \mathrm{mg} / \mathrm{dL}, p<0.01)$. Low-density lipoprotein cholesterol (LDL-c) levels decreased $11 \%$ in garlic-treated subjects, and only $3 \%$ in the placebo group $(p<0.05)$. No significant changes in serum high-density lipoprotein cholesterol (HDL-c), triglycerides, blood pressure, and glucose levels were observed. Thus, standardized garlic treatment ( $900 \mathrm{mg} /$ day) seemed to be most effective in reducing LDL-c levels [30].

Conversely, aged garlic extract supplementation was shown to be more effective than the placebo in lowering systolic blood pressure, similar to current first-line medications, in patients with treated but uncontrolled hypertension [27]. Kwai (900 mg garlic pill/day), for instance, was effective in treating mild and moderate arterial hypertension [28]. Quite the opposite, the same preparation had no significant effects on LDL oxidation, plasma lathosterol-I-cholestero1 ratio (a measure of cholesterol synthesis), nor LDL receptor expression in lymphocytes. Therefore, it was proposed by Simons et al. (1995) that garlic ingestion did not provide pronounced effects on lipids and lipoproteins [31]. Likewise, Kwai garlic (standardized to $0.6 \%$ allicin and $1.3 \%$ alliin) supplement cannot change the oxidized LDL levels. The results of this study do not support the hypothesis that dietary garlic supplementation decreases the LDL susceptibility to oxidation, and that LDL fraction patterns in plasma might be involved. Lipoprotein levels in plasma also were unchanged, although other mechanisms of cardiovascular protection were not excluded [41]. A meta-analysis did not suggest a significant effect of garlic supplementation on lipoprotein(a) (Lp (a)) level reduction [32]. A garlic treatment with a dose of $900 \mathrm{mg}$ garlic extract/tablet for 12 weeks does not affect major plasma lipoproteins and has no impact on HDL-c subclasses, Lp (a), apolipoprotein B, postprandial triglycerides or LDL-c subclass distribution [34]. Moreover, no significant effects on cardiovascular risk factors were stated in pediatric patients with familial hyperlipidemia [35], as well as being ineffective in reducing cholesterol levels [36]. Another study highlighted that a garlic powder preparation used in moderately hypercholesterolemic adults did not significantly affect plasma lipid levels, suggesting that there was no indication of a better effect by garlic doses over 0,500 , and $1000 \mathrm{mg} / \mathrm{day}$ [40]. Other authors also reported no significant changes in serum HDL-c, triglycerides, blood pressure, and glucose levels [30]. A garlic powder (800 mg/day) treatment, for example, led to a significant increase 
in walking distance ability and to a decrease in diastolic blood pressure, spontaneous thrombocyte aggregation, plasma viscosity, and cholesterol concentration [29]. Similarly, $900 \mathrm{mg}$ of garlic powder per day for four months significantly lowered total cholesterol, triglycerides, and blood pressure [33]. Another study found treatment with a garlic powder tablet for six months led to a $10 \%$ decrease in LDL-c levels in the garlic group compared to $6 \%$ in the placebo group [37]. Additionally, $600 \mathrm{mg} /$ day of a standardized dried garlic powder (1.3\% allicin) led to a total cholesterol drop from 223 to $214 \mathrm{mg} / \mathrm{dL}$ after 10 weeks, triglycerides considerably decreased from 124 to $118 \mathrm{mg} / \mathrm{dL}$, while blood pressure remained constant [38]. A standardized garlic powder $(900 \mathrm{mg} /$ day) also resulted in a greater reduction in serum total cholesterol and LDL-c [30], and an increase in HDL-c levels [42], and it has even been proposed that garlic ( $3 \mathrm{~g}$ of raw garlic daily) has a role in cholesterol management as an adjunctive therapy in most cases of hypercholesterolemia, thereby reducing the risk of atherosclerosis and cardiovascular events [39]. Also, a dried garlic extract preparation $(600 \mathrm{mg} /$ day) markedly decreased fibrinogen and fibrinopeptide A by $10 \%$, increased by $10 \%$ streptokinase activated plasminogen and fibrinopeptide B beta 15-42 coagulation factor and decreased serum cholesterol levels, systolic and diastolic blood pressure [43]. Interestingly, one study revealed that dried garlic powder tablets (10.8 mg alliin (3-(2-propenylsulfinyl)-L-alanine)/daily) have no clinically relevant lipid-lowering and blood pressure-lowering effects in middle-aged, normolipidemic individuals. Thus, the putative anti-atherosclerotic effect of garlic may be linked to risk markers other than blood lipids [45].

\subsubsection{Bodyweight Management}

Distinct clinical trials were already performed using garlic and its derived components on obese patients (Table 1). Garlic powder supplementation $(800 \mathrm{mg} /$ daily) resulted in a significant decrease in body weight and body fat mass $(p<0.05)$ [44]. Although some clinical trials using garlic tablets seem to relate the beneficial effects of garlic to allicin, this fact cannot be considered valid when the test shows no effect, unless the expected release of allicin from garlic tablets has been determined under the standardized conditions of drug release [46].

\subsection{Anti-Carcinogenic Activity}

Looking at allicin or allicin-containing products as anti-cancer agents (Table 2), allicin has been recently studied for its effectiveness on stage II oral submucous fibrosis in a Chinese patient cohort. During this randomized clinical trial, triamcinolone acetonide (TA) (2 mg/week) or allicin (1 mg/week) were injected intralesionally for 16 weeks. Group A corresponded to the triamcinolone acetonide group and Group B to the allicin-treated group. Mouth opening, burning sensation, and oral health-related quality of life (QoL) were assessed over time. Once the study was over, net gain in mouth opening was $2.27 \pm 0.84 \mathrm{~mm}$ in group $\mathrm{A}$ and $5.16 \pm 1.04 \mathrm{~mm}$ in group $\mathrm{B}$; the burning sensation improved by $2.79 \pm 0.87$ in group $A$ and by $4.33 \pm 1.04$ in group $B$, while the oral health impact profile (OHIP) score improved by $4.67 \pm 2.94$ in group A and by $12.58 \pm 9.82$ in group B. Concerning the 48 subjects included in this study, no adverse effects were stated, therefore highlighting the potential use of allicin as an adjunctive therapeutic drug [19]. Iang et al. (2015) found that allicin intralesional injection improved the associated signs and symptoms with stage II oral submucous fibrosis (OSF) without notable side effects [19]. 
Table 2. Clinical trials assessing anti-cancer effects of allicin or allicin-containing products/formulations.

\begin{tabular}{|c|c|c|c|c|c|}
\hline Clinical Trial & Participants & Duration & Dose & Summary & References \\
\hline \multirow[t]{2}{*}{$\mathrm{R}$} & 52 patients & 16 weeks & Allicin $(1 \mathrm{mg})$ was injected intralesionally & $\begin{array}{l}\text { Allicin improved the signs and symptoms associated with stage II oral submucous fibrosis } \\
\text { (OSF) without notable side effects }\end{array}$ & [19] \\
\hline & 51 patients & & AGE $(0.16-2.4 \mathrm{~mL})$ & AGE had a potential suppressive effect on colorectal adenomas in humans & [47] \\
\hline \multirow[t]{2}{*}{$\mathrm{R}, \mathrm{DB}$} & 3365 individuals & 7.3 years & AGE and steam-distilled garlic oil & No beneficial effects on precancerous gastric lesion prevalence or gastric cancer incidence & [48] \\
\hline & $>5000$ participants & & $200 \mathrm{mg}$ synthetic allitridum and $100 \mu \mathrm{g}$ selenium & $\begin{array}{l}\begin{array}{l}\text { Large doses of allitridum and microdoses of selenium may effectively prevent gastric } \\
\text { cancer, especially in men }\end{array}\end{array}$ & [49] \\
\hline & $\begin{array}{l}50 \text { patients (42 with liver cancer, } 7 \text { with } \\
\text { pancreatic cancer and } 1 \text { with colon cancer) }\end{array}$ & & AGE & $\begin{array}{l}\text { A marked improvement on natural killer (NK) cell activity, but no improvement in quality } \\
\text { of life }\end{array}$ & [50] \\
\hline
\end{tabular}

DB, double-blinded; PC, placebo controlled; R, randomized. 
Previously, Lawson et al. (2001) analyzed the allicin release from garlic powder tablets under simulated gastrointestinal conditions and found that tablets provided less protection over allicin due to its fast disintegration, release of low allicin amounts and vice versa [46]. Besides, aged garlic extract also has shown a suppressive effect on colorectal adenomas in humans through multiple pathways, i.e., reducing cancer incidence and suppressing its growth and proliferation [47]. Actually, aged garlic administration in patients with advanced cancer of the digestive system led to an improvement of natural killer (NK) cell activity but did not cause improvement in QoL [50]. Also, the use of large doses of allitridum and microdoses of selenium have evidenced to effectively prevent gastric cancer, especially in men [49]. Garlic supplementation, however, had no beneficial effects on precancerous gastric lesion prevalence or gastric cancer incidence [48]. Thus, the main findings from clinical trials assessing the allicin or allicin-containing products' anticancer effects have been associated with improvements at stage II oral submucous fibrosis and on natural killer cell activity, with a suppressive effect on colorectal adenomas and effective prevention of gastric cancer in humans without notable side effects. No beneficial effects, however, have been reported on precancerous gastric lesion prevalence in gastric cancer and QoL.

\subsection{Antidiabetic Activity}

The garlic effects on both lipid and glucose levels have been increasingly reported (Table 3) as well as its therapeutic efficacy in patients suffering from cardiovascular diseases and diabetes [51]. Actually, daily garlic allicin supplementation $(0.05-1.5 \mathrm{~g})$ displayed a positive and sustained role in blood glucose, total cholesterol (TC), and high/low density lipoprotein (HDL-c/LDL-c) regulation in type 2 diabetes mellitus (T2DM) management [52]. Conversely, two tablets of garlic three times/day (each tablet containing $400 \mathrm{mg}$ dry garlic powder and over $1000 \mathrm{mg}$ allicin) reduced fasting blood sugar (FBS) and hemoglobin A1c (HbA1c) in T2DM patients. Hence, it may be a candidate drug in the treatment of diabetes mellitus [53]. Also, a marked FBS reduction and $\mathrm{HbA1C}$ improvement were stated after garlic treatment at high doses (1200 mg/day) [54]. The garlic powder tablet Allicor treatment resulted in a better metabolic control due to a marked reduction in FBS, serum fructosamine and serum triglyceride levels [55]. Additionally, a combination of turmeric and garlic extracts at a dose of $2.4 \mathrm{~g} /$ day led to a marked reduction in FBS, $2 \mathrm{~h}$ postprandial glucose, HbA1C, TC, LDL-c and triglyceride levels, as well as a body mass index more than the two other dosages, without exerting side effects on kidney and liver functions [56]. A study also emphasized that garlic capsule intake $(900 \mathrm{mg} /$ day) led to a marked improvement in blood pressure in diabetic patients, suggesting that garlic supplementation can be useful in both treating and controlling diabetes complications in the future [57], aside from being able to decrease FBS, especially in patients suffering from both diabetes and hypercholesterolemia [58]. Double-blinded, placebo-controlled, randomized clinical trials indicated than allicin or allicin-containing products play a positive and sustained role in blood sugar, total cholesterol, and high/low density lipoprotein regulation in diabetic patients. Additionally, no side effects have been observed on kidney and liver functions.

\subsection{Cytochrome Activity}

The beneficial effects of garlic and its derived products also have been assessed on cytochrome activity (Table 4). Garlic oil was able to markedly decrease (39\%) 6-hydroxychlorzoxazone/chlorzoxazone serum ratios, suggesting CYP2E1 (cytochrome P450 2E1) inhibition [59]. Additionally, there was a marked inter-subject variation on ritonavir pharmacokinetics after garlic application, suggesting that a combination of ritonavir with garlic may act as an inducer and inhibitor of CYP3A4 (cytochrome P450 3A4) and P-gp (P-glycoprotein) activity [60]. It also was proposed, however, that the probable intestinal P-gp or cytochrome P-450 induction by garlic or saquinavir metabolites may decrease drug availability [61]. Actually, in another study, no significant differences on cytochrome p450 2D6 and 3A4 activity were found in healthy volunteers [62]. 
Table 3. Clinical trials assessing antidiabetic effects of allicin or allicin-containing products/formulations.

\begin{tabular}{|c|c|c|c|c|c|}
\hline Clinical Trial & Participants & Duration & Dose & Summary & References \\
\hline $\mathrm{R}, \mathrm{DB}$ & 30 individuals & 3 months & $\begin{array}{l}2 \text { garlic tablets, } 3 \text { times/day (each tablet containing } \\
400 \mathrm{mg} \text { dry garlic powder and over } 1000 \mathrm{mg} \text { allicin) }\end{array}$ & Garlic significantly reduced fasting blood sugar (FBS) and HbA1c in T2DM & [53] \\
\hline PC & 210 individuals & 24 weeks & Garlic tablets at $300,600,900,1200$ and $1500 \mathrm{mg} /$ day & Significant reduction in $\mathrm{FBS}$ and improvement in $\mathrm{HbA1C}$ were observed at higher garlic doses & [54] \\
\hline $\mathrm{DB}, \mathrm{PC}$ & 60 individuals & 4 weeks & Garlic powder tablet Allicor & Better metabolic control due to the lowering of FBS, serum fructosamine and triglyceride levels & [55] \\
\hline $\mathrm{DB}, \mathrm{R}$ & 32 individuals & 12 weeks & $\begin{array}{l}\text { Combination of turmeric and garlic extracts: } 1.2,1.6 \\
\text { and } 2.4 \mathrm{~g} / \text { day }\end{array}$ & $\begin{array}{c}2.4 \mathrm{~g} / \text { day decreased FBS, } 2 \mathrm{~h} \text { postprandial glucose level, } \mathrm{HbA1C} \text {, total cholesterol, LDL-c, triglyceride, and } \\
\text { body mass index more than the two other dosages (1.2 and } 1.6 \mathrm{~g} / \text { day). No side effects were observed on } \\
\text { kidney and liver functions }\end{array}$ & [56] \\
\hline $\mathrm{R}, \mathrm{PC}$ & 25 individuals & 2 months & $900 \mathrm{mg}$ of garlic capsules & $\begin{array}{l}\text { Improvement in blood pressure in diabetic patients. Garlic supplementation can be useful in controlling } \\
\text { complications and treating diabetes in the future }\end{array}$ & [57] \\
\hline Meta-analysis & 768 individuals & & $\begin{array}{l}\text { Daily garlic (allicin) supplement ranged from } \\
0.05-1.5 \mathrm{~g}\end{array}$ & $\begin{array}{l}\text { Garlic supplement played a positive and sustained role in blood glucose, total cholesterol, and } \\
\text { high/low-density lipoprotein regulation in T2DM }\end{array}$ & [52] \\
\hline Meta-analysis & & & & $\begin{array}{l}\text { Garlic reduced lipid profiles and glucose parameters, being therapeutically effective in patients suffering from } \\
\text { cardiovascular diseases and diabetes }\end{array}$ & [51] \\
\hline Meta-analysis & & & & $\begin{array}{c}\text { Garlic consumption could significantly decrease FBS especially in patients suffering from both diabetes and } \\
\text { hypercholesterolemia }\end{array}$ & [58] \\
\hline
\end{tabular}

DB, double-blinded; PC, placebo-controlled; R, randomized 
Piscitelli and co-authors have investigated the effect of garlic supplements on the pharmacokinetics of saquinavir. They reported that AUC (area under the curve) and Cmax (maximum concentrations) decreased by $51 \%$ and $54 \%$, respectively [61]. Found in another study, Gallicano et al. studied the effect of short-term administration of garlic supplements on single-dose ritonavir pharmacokinetics in healthy volunteers which indicated it did not significantly alter the single-dose ritonavir pharmacokinetics. The AUC and Cmax decreased by $-17 \%$ and 1\%, respectively [60]. Berginc and Kristl data on Michaelis-Menten kinetics showed competitive inhibition of CYP3A4, with enzyme activity reduced to $70-80 \%$ of control. They have demonstrated increased efflux of darunavir (human immunodeficiency virus protease inhibitor (HIV-PI), approved in 2006) by P-Glycoprotein (Pgp) in the presence of a garlic supplement and summarized that the garlic products with high contents of mainly sulfur-containing compounds will be expected to lead to pharmacokinetic changes [63].

\subsection{Oxidative Stress Status}

Oxidative stress status has been increasingly correlated with multiple oxidative stress-related disorders [64]. Indeed, some clinical studies were already performed to assess the effects of allicin or allicin-containing products/formulations on the oxidative stress status (Table 4). Garlic supplementation (600 mg/daily), for instance, markedly reduced the susceptibility of apolipoprotein B-containing lipoproteins for oxidation [65]. Additionally, after a 2-month application of coated garlic powder tablets (900 mg with alliin and allicin contents of $1.3 \%$ and $0.6 \%$, respectively), the glutathione (GSH) concentration significantly increased in circulating human erythrocytes [66].

\subsection{Preeclampsia}

Several clinical trials were already developed to assess the allicin or allicin-containing products' effects on preeclampsia (Table 4). Aalami-Harandi et al. (2015) showed that the intake of one garlic tablet (containing $400 \mathrm{mg}$ garlic and $1 \mathrm{mg}$ allicin) once daily led to a significant decrease in highly-sensitive C-reactive protein (hs-CRP) and increased GSH, but did not affect lipid profiles, total antioxidant capacity (TAC) and pregnancy outcomes [67]. Alternately, Ziaei et al. (2001) stated that a daily intake of a garlic tablet $(800 \mathrm{mg})$ effectively reduced the occurrence of hypertension during the third trimester of pregnancy, but it was not effective in preventing preeclampsia [68]. 
Table 4. Other clinical effects of allicin or allicin-containing products/formulations.

\begin{tabular}{|c|c|c|c|c|c|}
\hline Clinical Trial & Participants & Duration & Dose & Summary & Reference \\
\hline \multicolumn{6}{|c|}{ Cytochrome 450} \\
\hline $\mathrm{R}$ & 12 healthy volunteers & 28 days & $\begin{array}{l}\text { Probe-drug cocktails (caffeine } 100 \mathrm{mg} \text {, midazolam } \\
\text { 8mg, chlorzoxazone } 500 \mathrm{mg} \text { and debrisoquin } 5 \mathrm{mg} \text { ) } \\
\text { were daily administered before supplementation } \\
\text { (baseline) and at the end of supplementation (1500 mg } \\
\text { of garlic oil) }\end{array}$ & $\begin{array}{l}\text { Garlic oil significantly decreased 6-hydroxychlorzoxazone/chlorzoxazone serum ratios by } 39 \%(p=0.03) \text {, suggesting } \\
\text { CYP2E1 inhibition }\end{array}$ & [59] \\
\hline $\mathrm{R}$ & 10 healthy volunteers & 4 days & $\begin{array}{l}20 \mathrm{mg} \text { of garlic extract, with a single dose of ritonavir } \\
\text { (a substrate of CYP3A4 and P-gp) co-administered on } \\
\text { the last day }\end{array}$ & $\begin{array}{l}\text { Garlic supplement decreased the peak plasma concentration of ritonavir by } 1 \% \text {, and the area under the plasma } \\
\text { concentration-time curve by } 17 \% \text {. Garlic showed a large inter-subject variation on ritonavir pharmacokinetics, } \\
\text { suggesting that combination of ritonavir with garlic may be both an inducer and inhibitor of CYP3A4 and P-gp }\end{array}$ & [60] \\
\hline $\mathrm{R}$ & 10 healthy volunteers & 21 days & $\begin{array}{l}\text { Garlic tablet (containing allicin } 4.64 \mathrm{mg} \text { and alliin } \\
11.2 \mathrm{mg} \text { ) twice daily for } 21 \text { days, with a } 1200 \mathrm{mg} \text { dose } \\
\text { of saquinavir, thrice daily on the last } 3 \text { days of garlic } \\
\text { supplementation. After a 10-day garlic washout } \\
\text { period, saquinavir was administered again for } 3 \text { days } \\
\text { at the same dosage }\end{array}$ & $\begin{array}{l}\text { Authors suggested that the effect of garlic supplements on the pharmacokinetics of saquinavir may be related to } \\
\text { differences in CYP3A4 content, differences in the metabolism or absorption of garlic }\end{array}$ & [61] \\
\hline \multicolumn{6}{|c|}{ Cytochrome P450 2D6 and 3A4 } \\
\hline & 40 healthy volunteers & 14days & $\begin{array}{l}1800 \mathrm{mg} \text { tablets of a garlic extract containing allicin, } \\
\text { alliin and alliinase twice daily }\end{array}$ & $\begin{array}{l}\text { No significant differences on pharmacokinetic parameters were found (maximum concentration in plasma, } 27.3 \pm 2.6 \\
\mathrm{ng} / \mathrm{mL} \text { versus } 27.3 \pm 4.8 \mathrm{ng} / \mathrm{mL} \text {; time to reach maximum concentration in plasma, } 1.9 \pm 1.4 \mathrm{~h} \text { versus } 2.4 \pm 1.8 \mathrm{~h} \text {; area } \\
\text { under the time-versus-concentration curve, } 537 \pm 94 \mathrm{~h} \mathrm{ng} \mathrm{mL}-1 \text { versus } 548 \pm 159 \mathrm{~h} \mathrm{ng} \mathrm{mL}^{-1} \text {; half-life of elimination, } \\
13.7 \pm 4.4 \mathrm{~h} \text { versus } 14.5 \pm 4.3 \mathrm{~h} \text { ) }\end{array}$ & [62] \\
\hline \multicolumn{6}{|c|}{ Oxidative stress status } \\
\hline \multirow[t]{2}{*}{$\mathrm{DB}, \mathrm{R}, \mathrm{PC}$} & 10 individuals & 2 weeks & $600 \mathrm{mg} /$ daily & Reduced the susceptibility of apolipoprotein B-containing lipoproteins to oxidation & [65] \\
\hline & 25 individuals & 2 months & $\begin{array}{l}\text { Coated garlic powder tablets }(900 \mathrm{mg} \text { with an alliin } \\
\text { content of } 1.3 \% \text { and an allicin content of } 0.6 \% \text { ) }\end{array}$ & $\begin{array}{l}\text { Significant increase in reduced glutathione (GSH) concentration in circulating human erythrocytes after the } \\
\qquad \text {-month period }\end{array}$ & [66] \\
\hline \multicolumn{6}{|c|}{ Preeclampsia } \\
\hline $\mathrm{R}, \mathrm{DB}, \mathrm{PC}$ & 44 individuals & 9 weeks & $\begin{array}{l}\text { Garlic tablet (400 } \mathrm{mg} \text { garlic and } 1 \mathrm{mg} \text { allicin) once } \\
\text { daily }\end{array}$ & $\begin{array}{l}\text { Decreased hs-CRP (the high-sensitivity C-reactive protein) and increased GSH, but did not affect lipid profiles, total } \\
\text { antioxidant capacity, and pregnancy outcomes }\end{array}$ & [67] \\
\hline $\mathrm{R}, \mathrm{DB}, \mathrm{PC}$ & 300 individuals & 8 weeks & Garlic tablet (800 mg) & $\begin{array}{l}\text { Reduced the occurrence of hypertension alone, but it was not effective in prevention of preeclampsia in the third } \\
\text { trimester of pregnancy }\end{array}$ & [68] \\
\hline \multicolumn{6}{|c|}{ Anti-ulcer (H. pylori infection) } \\
\hline & 20 individuals & 14 days & Allicin $(800 \mathrm{mg} /$ daily $)$ & After allicin-treatment, $H$. pylori infection was still found in all patients & {$[69,70]$} \\
\hline & 210 individuals & 14 days & Allicin $(1200-4200 \mu \mathrm{g} /$ daily $)$ & Allicin was potentially effective on $H$. pylori eradication & {$[69,71]$} \\
\hline $\begin{array}{l}\text { Open-Label, } \\
\text { Randomized }\end{array}$ & 112 patients & 14 days & $\begin{array}{l}\text { Allicin ( } 24 \mathrm{mg} / \text { daily) and omeprazole } 20 \mathrm{mg}, \\
\text { amoxicillin } 2000 \mathrm{mg} / \text { daily }\end{array}$ & Eradication rate was $73 \%$ in allicin-based therapy & [72] \\
\hline $\mathrm{R}, \mathrm{DB}, \mathrm{PC}$ & 96 individuals & 5 days & Allicin $(10 \mathrm{mg} /$ daily $)$ & Allicin adhesive tablets were effective in reducing ulcer size and alleviating ulcer pain without significant side effects & [21] \\
\hline \multicolumn{6}{|c|}{ Male genital wart } \\
\hline $\mathrm{DB}, \mathrm{R}, \mathrm{PC}$ & 35 male patients & 2 months & $10 \%$ garlic extract & $\begin{array}{l}\text { Garlic extract had a similar effect of cryotherapy. The majority of patients }(69.7 \%) \text { showed complete clearing of the } \\
\text { lesions in the garlic group while complete clearing was observed in } 78.8 \% \text { of patients in the cryotherapy group. }\end{array}$ & [73] \\
\hline \multicolumn{6}{|c|}{ Common cold prevention } \\
\hline $\mathrm{DB}, \mathrm{PC}$ & 146 volunteers & 12 weeks & $\begin{array}{l}\text { Allicin-containing garlic supplement, one } \\
\text { capsule daily }\end{array}$ & Allicin-containing supplement seemed to prevent attack by the common cold virus & [74] \\
\hline
\end{tabular}

DB, double-blinded; PC, placebo-controlled; R, randomized. 


\subsection{Antimicrobial Effects}

Several studies have been performed to access allicin and allicin-containing product antimicrobial effects. Zhang et al. (1992), for example, reported that the use of allicin for thrush prevention in infants led to a marked decrease in disease incidence when compared to controls, while to sodium bicarbonate no significant changes were stated. These findings suggest that both allicin and sodium bicarbonate are effective against thrush, but allicin proved to be more effective $[75,76]$. Other studies state that allicin may also be an alternative for antibiotics [77,78], more specifically against Helicobacter pylori infections (Table 4).

\subsection{Ulcer Healing}

Allicin treatment ( $800 \mathrm{mg} /$ daily) over a period of 14 days on H. pylori infection did not lead to a complete eradication, since $H$. pylori was still found in all patients $[69,70]$. Conversely, the application of an allicin dose of $4.2 \mathrm{mg} /$ daily was potentially effective in $H$. pylori eradication [69,71]. The eradication rate in an allicin-based therapy, with an allicin dose of $24 \mathrm{mg} /$ daily, omeprazole $20 \mathrm{mg}$ and amoxicillin $2000 \mathrm{mg} /$ day, was 73\% [72]. Additionally, the use of allicin adhesive tablets (allicin $10 \mathrm{mg} /$ day) was effective in reducing ulcer size and in alleviating ulcer pain, without displaying significant side effects [21].

\subsection{Others}

Garlic preparations also have shown to be effective in male genital warts; indeed, the application of a $10 \%$ garlic extract for 2 months in male genital warts had similar effects when compared with cryotherapy [73]. Alternatively, an allicin-containing preparation also was tested for its ability to prevent the common cold, and the results revealed a great ability to avoid the common cold virus attack [74].

\section{Conclusions}

Garlic preparations have revealed promising effects for many health conditions, including hyperlipidemia, hypertension, obesity, atherosclerosis, cancer, diabetes, ulcers and even infection. While the cholesterol-lowering effects of garlic is the most widely recognized activity, it has been increasingly stated that its bioactive effects are mostly related to its content in sulphur compounds, among them allicin. It is worth noting that further studies still need to be performed to deepen the knowledge on some other crucial aspects, such as on the quality and safety parameters, purity, origin, stability, bioavailability, bioefficacy and even middle-long term side effects and toxicity. Actually, allicin instability is one of the aspects that has most limited the progress of clinical studies and their respective applications. The focus on techniques, such as encapsulation, microspheres and spray drying, as well as self-nanoemulsifying systems for the production of more effective garlic preparations have been the subject of extreme interest and dedication. Self-nanoemulsifying systems also have shown good physical attributes, besides appearing effective for drug release.

Author Contributions: Conceptualization, J.S.-R.; validation, investigation, resources, data reviewing and writing, all authors; review and editing, J.S.-R., I.D.B., F.S., N.M. and W.C.C. All authors read and approved the final manuscript.

Funding: Natália Martins would like to thank the Portuguese Foundation for Science and Technology (FCT-Portugal) for the Strategic project ref. UID/BIM/04293/2013 and “NORTE2020-Programa Operacional Regional do Norte" (NORTE-01-0145-FEDER-000012).

Conflicts of Interest: The authors declare no conflict of interest.

\section{References}

1. Fabricant, D.S.; Farnsworth, N.R. The value of plants used in traditional medicine for drug discovery. Environ. Health Perspect. 2001, 109, 69-75. [PubMed] 
2. Hechtman, L. Clinical Naturopathic Medicine; Elsevier Health Sciences: Amsterdam, The Netherlands, 2018.

3. Sharifi-Rad, M.; Fokou, P.; Sharopov, F.; Martorell, M.; Ademiluyi, A.; Rajkovic, J.; Salehi, B.; Martins, N.; Iriti, M.; Sharifi-Rad, J. Antiulcer agents: From plant extracts to phytochemicals in healing promotion. Molecules 2018, 23, 1751. [CrossRef] [PubMed]

4. Mishra, A.P.; Saklani, S.; Salehi, B.; Parcha, V.; Sharifi-Rad, M.; Milella, L.; Iriti, M.; Sharifi-Rad, J.; Srivastava, M. Satyrium nepalense, a high altitude medicinal orchid of Indian Himalayan region: Chemical profile and biological activities of tuber extracts. Cell. Mol. Biol. 2018, 64, 35. [CrossRef] [PubMed]

5. Sharifi-Rad, J.; Sharifi-Rad, M.; Salehi, B.; Iriti, M.; Roointan, A.; Mnayer, D.; Soltani-Nejad, A.; Afshari, A. In vitro and in vivo assessment of free radical scavenging and antioxidant activities of Veronica persica Poir. Cell. Mol. Biol. 2018, 64, 57. [CrossRef] [PubMed]

6. Sharifi-Rad, M.; Roberts, T.H.; Matthews, K.R.; Bezerra, C.F.; Morais-Braga, M.F.B.; Coutinho, H.D.M.; Sharopov, F.; Salehi, B.; Yousaf, Z.; Sharifi-Rad, M.; et al. Ethnobotany of the genus Taraxacum-Phytochemicals and antimicrobial activity. Phytotherapy Res. 2018, 32, 2131-2145. [CrossRef] [PubMed]

7. Salehi, B.; Fokou, P.V.T.; Sharifi-Rad, M.; Zucca, P.; Pezzani, R.; Martins, N.; Sharifi-Rad, J. The therapeutic potential of naringenin: A review of clinical trials. Pharmaceuticals 2019, 12, 11. [CrossRef]

8. Salehi, B.; Venditti, A.; Sharifi-Rad, M.; Kregiel, D.; Sharifi-Rad, J.; Durazzo, A.; Lucarini, M.; Santini, A.; Souto, E.B.; Novellino, E.; et al. The therapeutic potential of Apigenin. Int. J. Mol. Sci. 2019, $20,1305$. [CrossRef]

9. Mattioli, L.; Funari, C.; Perfumi, M. Effects of Rhodiola rosea L. extract on behavioural and physiological alterations induced by chronic mild stress in female rats. J. Psychopharmacol. 2009, 23, 130-142. [CrossRef]

10. Chan, J.Y.Y.; Yuen, A.C.; Chan, R.Y.; Chan, S. A review of the cardiovascular benefits and antioxidant properties of allicin. Phytother. Res. 2013, 27, 637-646. [CrossRef]

11. Khalighi-Sigaroodi, F.; Jeddi-Tehrani, M.; Ahvazi, M.; Shahnazi, S.; Bayat, A.A.; Mohajer, N.; Zarei, S. Cytotoxicity evaluation of Taverniera spartea on human cancer cell lines. J. Med. Plants 2014, 2, 114-128.

12. Forouzandeh, F.; Salimi, S.; Naghsh, N.; Zamani, N.; Jahani, S. Evaluation of anti-cancer effect of Peganum harmala L hydroalcholic extract on human cervical carcinoma epithelial cell line. J. Shahrekord Univ. Med. Sci. 2014, 16, 1-8.

13. Salehi, B.; Sharopov, F.; Martorell, M.; Rajkovic, J.; Ademiluyi, A.O.; Sharifi-Rad, M.; Fokou, P.V.T.; Martins, N.; Iriti, M.; Sharifi-Rad, J. Phytochemicals in Helicobacter pylori infections: What are we doing now? Int. J. Mol. Sci. 2018, 19, 2361. [CrossRef] [PubMed]

14. Marasini, B.P.; Baral, P.; Aryal, P.; Ghimire, K.R.; Neupane, S.; Dahal, N.; Singh, A.; Ghimire, L.; Shrestha, K. Evaluation of antibacterial activity of some traditionally used medicinal plants against human pathogenic bacteria. BioMed Res. Int. 2015. [CrossRef] [PubMed]

15. Ryu, J.H.; Kang, D. Physicochemical properties, biological activity, health benefits, and general limitations of aged black garlic: a review. Molecules 2017, 22, 919. [CrossRef]

16. Peng, Y.; Hu, K. Effect of garlic on rats with chronic intermittent hypoxia combined with diabetes mellitus. Mol. Med. Rep. 2018, 17, 6174-6184. [CrossRef]

17. Mikaili, P.; Maadirad, S.; Moloudizargari, M.; Aghajanshakeri, S.; Sarahroodi, S. Therapeutic uses and pharmacological properties of garlic, shallot, and their biologically active compounds. Iran. J. Basic Med. Sci. 2013, 16, 1031-1048.

18. Okada, Y.; Tanaka, K.; Fujita, I.; Sato, E.; Okajima, H. Antioxidant activity of thiosulfinates derived from garlic. Redox Rep. 2005, 10, 96-102. [CrossRef]

19. Jiang, X.; Zhang, Y.; Li, F.; Zhu, Y.; Chen, Y.; Yang, S.; Sun, G. Allicin as a possible adjunctive therapeutic drug for stage II oral submucous fibrosis: A preliminary clinical trial in a Chinese cohort. Int. J. Oral Maxillofac. Surg. 2015, 44, 1540-1546. [CrossRef]

20. D'Argenio, G.; Mazzone, G.; Ribecco, M.T.; Lembo, V.; Vitaglione, P.; Guarino, M. Garlic extract attenuating rat liver fibrosis by inhibiting TGF- $\beta 1$. Clin. Nutr. 2013, 32, 252-258. [CrossRef]

21. Jiang, X.W.; Zhang, Y.; Song, G.D.; Li, F.F.; Peng, H.Y.; Yang, S.K.; Sun, G.L. Clinical evaluation of allicin oral adhesive tablets in the treatment of recurrent aphthous ulceration. Oral Surg. Oral Med. Oral Pathol. Oral Radiol. 2012, 113, 500-504. [CrossRef] 
22. Gardner, C.D.; Lawson, L.D.; Block, E.; Chatterjee, L.M.; Kiazand, A.; Balise, R.R.; Kraemer, H.C. Effect of raw garlic vs. commercial garlic supplements on plasma lipid concentrations in adults with moderate hypercholesterolemia. Arch. Intern. Med. 2007, 167, 346-353. [CrossRef] [PubMed]

23. Koscielny, J.; Klussendorf, D.; Latza, R.; Schmitt, R.; Radtke, H.; Siegel, G.; Kiesewetter, H. The antiatherosclerotic effect of Allium sativum. Atherosclerosis 1999, 144, 237-249. [CrossRef]

24. Budoff, M.J.; Ahmadi, N.; Gul, K.M.; Liu, S.T.; Flores, F.R.; Tiano, J.; Takasu, J.; Miller, E.; Tsimikas, S. Aged garlic extract supplemented with B vitamins, folic acid and L-arginine retards the progression of subclinical atherosclerosis: A randomized clinical trial. Prev. Med. 2009, 49, 101-107. [CrossRef] [PubMed]

25. Orekhov, A.N.; Sobenin, I.A.; Korneev, N.V.; Kirichenko, T.V.; Myasoedova, V.A.; Melnichenko, A.A.; Balcells, M.; Edelman, E.R.; Bobryshev, Y.V. Anti-atherosclerotic therapy based on botanicals. Recent Pat. Cardiovasc. Drug Discov. 2013, 8, 56-66. [CrossRef] [PubMed]

26. Larijani, V.N.; Ahmadi, N.; Zeb, I.; Khan, F.; Flores, F.; Budoff, M. Beneficial effects of aged garlic extract and coenzyme Q10 on vascular elasticity and endothelial function: The FAITH randomized clinical trial. Nutrition 2013, 29, 71-75. [CrossRef] [PubMed]

27. Ried, K.; Frank, O.R.; Stocks, N.P. Aged garlic extract lowers blood pressure in patients with treated but uncontrolled hypertension: A randomised controlled trial. Maturitas 2010, 67, 144-150. [CrossRef]

28. Sobenin, I.A.; Andrianova, I.V.; Fomchenkov, I.V.; Gorchakova, T.V.; Orekhov, A.N. Time-released garlic powder tablets lower systolic and diastolic blood pressure in men with mild and moderate arterial hypertension. Hypertens Res. 2009, 32, 433-437. [CrossRef]

29. Kiesewetter, H.; Jung, F.; Jung, E.M.; Blume, J.; Mrowietz, C.; Birk, A.; Koscielny, J.; Wenzel, E. Effects of garlic coated tablets in peripheral arterial occlusive disease. Clin. Investig. 1993, 71, 383-386. [CrossRef]

30. Jain, A.K.; Vargas, R.; Gotzkowsky, S.; McMahon, F.G. Can garlic reduce levels of serum lipids? A controlled clinical study. Am. J. Med. 1993, 94, 632-635. [CrossRef]

31. Simons, L.A.; Balasubramaniam, S.; Konigsmark, M.; Parfitt, A.; Simons, J.; Peters, W. On the effect of garlic on plasma lipids and lipoproteins in mild hypercholesterolaemia. Atherosclerosis 1995, 113, $219-225$. [CrossRef]

32. Sahebkar, A.; Serban, C.; Ursoniu, S.; Banach, M. Effect of garlic on plasma lipoprotein(a) concentrations: A systematic review and meta-analysis of randomized controlled clinical trials. Nutrition 2016, 32, 33-40. [CrossRef] [PubMed]

33. Vorberg, G.; Schneider, B. Therapy with garlic: Results of a placebocontrolled, double blind study. J. Clin. Pract. 1990, 44, 7-11.

34. Superko, H.R.; Krauss, R.M. Garlic powder, effect on plasma lipids, postprandial lipemia, low-density lipoprotein particle size, high-density lipoprotein subclass distribution and lipoprotein(a). J. Am. Coll. Cardiol. 2000, 35, 321-326. [CrossRef]

35. McCrindle, B.; Helden, E.; Conne, W. Garlic extract therapy in children with hypercholesterolemia. Arch. Pediatrics Adolesc. Med. 1998, 152, 1089-1094. [CrossRef]

36. Isaacsohn, J.L.; Moser, M.; Stein, E.A.; Dudley, K.; Davey, J.A.; Liskov, E.; Black, H.R. Garlic powder and plasma lipids and lipoproteins: A multicenter, randomized, placebo-controlled trial. Arch. Intern. Med. 1998, 158, 1189-1194. [CrossRef]

37. De Santos, A.O.S.; Grunwald, J. Effect of garlic powder tablets on blood lipids and blood pressure-A six month placebo controlled, double blind study. Br. J. Clin. Res. 1993, 4, 37-44.

38. Saradeth, T.; Seidl, S.; Resch, K.; Ernst, E. Does garlic alter the lipid pattern in normal volunteers? Phytomedicine 1994, 1, 183-185. [CrossRef]

39. Lachhiramka, P.; Patil, S. Cholesterol lowering property of garlic (Allium sativum) on patients with hypercholesterolemia. Int. J. Med. Sci. Public Health 2016, 5, 2249-2251. [CrossRef]

40. Gardner, C.D.; Chatterjee, L.M.; Carlson, J.J. The effect of a garlic preparation on plasma lipid levels in moderately hypercholesterolemic adults. Atherosclerosis 2001, 154, 213-220. [CrossRef]

41. Byrne, D.J.; Neil, H.A.W.; Vallance, D.T.; Winder, A.F. A pilot study of garlic consumption shows no significant effect on markers of oxidation or sub-fraction composition of low-density lipoprotein including lipoprotein(a) after allowance for non-compliance and the placebo effect. Clin. Chim. Acta 1999, 285, 21-33. [CrossRef]

42. Holzgartner, H.; Schmidt, U.; Kuhn, U. Comparison of the efficacy and tolerance of a garlic preparation vs. bezafibrate. Arzneim. Frosch. 1992, 42, 1473-1477. 
43. Harenberg, J.; Giese, C.; Zimmermann, R. Effect of dried garlic on blood coagulation, fibrinolysis, platelet aggregation and serum cholesterol levels in patients with hyperlipoproteinemia. Atherosclerosis 1988, 74, 247-249. [CrossRef]

44. Soleimani, D.; Paknahad, Z.; Askari, G.; Iraj, B.; Feizi, A. Effect of garlic powder consumption on body composition in patients with nonalcoholic fatty liver disease: A randomized, double-blind, placebo-controlled trial. Adv. Biomed. Res. 2016, 5. [CrossRef]

45. Turner, B.; Molgaard, C.; Marckmann, P. Effect of garlic (Allium sativum) powder tablets on serum lipids, blood pressure and arterial stiffness in normo-lipidaemic volunteers: A randomized, double-blind, placebo-controlled trial. Br. J. Nutr. 2004, 92, 701-706. [CrossRef] [PubMed]

46. Lawson, L.D.; Wang, Z.J.; Papadimitriou, D. Allicin release under simulated gastrointestinal conditions from garlic powder tablets employed in clinical trials on serum cholesterol. Planta Med. 2001, 67, 13-18. [CrossRef] [PubMed]

47. Tanaka, S.; Haruma, K.; Yoshihara, M.; Kajiyama, G.; Kira, K.; Amagase, H.; Chayama, K. Aged garlic extract has potential suppressive effect on colorectal adenomas in humans. J. Nutr. 2006, 136, 821S-826S. [CrossRef]

48. You, W.C.; Brown, L.M.; Zhang, L.; Li, J.Y.; Jin, M.L.; Chang, Y.S.; Ma, J.L.; Pan, K.F.; Liu, W.D.; Hu, Y.; et al. Randomized double-blind factorial trial of three treatments to reduce the prevalence of precancerous gastric lesions. J. Natl. Cancer Inst. 2006, 98, 974-983. [CrossRef]

49. Li, H.; Li, H.Q.; Wang, Y. An intervention study to prevent gastric cancer by micro-selenium and large dose of allitridum. Chin. Med. J. 2004, 117, 1155-1160.

50. Ishikawa, H.; Saeki, T.; Otani, T.; Suzuki, T.; Shimozuma, K.; Nishino, H.; Fukuda, S.; Morimoto, K. Aged garlic extract prevents a decline of NK cell number and activity in patients with advanced cancer. J. Nutr. 2006, 136, 816S-820S. [CrossRef]

51. Shabani, E.; Sayemiri, K.; Mohammadpour, M. The effect of garlic on lipid profile and glucoseparameters in diabetic patients: A systematicreview and meta-analysis. Prim. Care Diabetes 2019, 13, 28-42. [CrossRef]

52. Wang, J.; Zhang, X.; Lan, H.; Wang, W. Effect of garlic supplement in the management of type 2 diabetes mellitus (T2DM): A meta-analysis of randomized controlled trials. Food Nutr. Res. 2017, 61. [CrossRef] [PubMed]

53. Ebadi, S.A.; Lenji, E.R.; Taghadosi, M.; Khorshidi, A.; Akbari, H. Effect of garlic on blood sugar in patients with type 2 diabetes mellitus. FEYZ 2007, 11, 20-25.

54. Ashraf, R.; Khan, R.A.; Ashraf, I. Effects of garlic on blood glucose levels and HbA1c in patients with type 2 diabetes mellitus. J. Med. Plants Res. 2011, 5, 2922-2928.

55. Sobenin, I.A.; Nedosugova, L.V.; Filatova, L.V.; Balabolkin, M.I.; Gorchakova, T.V.; Orekhov, A.N. Metabolic effects of time-released garlic powder tablets in type 2 diabetes mellitus: The results of double-blinded placebo-controlled study. Acta Diabetol. 2008, 45, 1-6. [CrossRef]

56. Sukandar, E.Y.; Permana, H.; Adnyana, I.K.; Sigit, J.I.; Ilyas, R.A.; Hasimun, P.; Mardiyah, D. Clinical study of turmeric (Curcuma longa L.) and garlic (Allium sativum L.) extracts as antihyperglycemic and antihyperlipidemic agent in type-2 diabetes-dyslipidemia patients. Int. J. Pharmacol. 2010, 6, 456-463. [CrossRef]

57. Mansouri, A.; Vahed, A.S.; Shahdadi, H.; Dashtban, F.; Arbabisarjou, A. The effect of garlic and cumin on blood pressure and glycosylated hemoglobin in patients with type 2 diabetes. Bali Med. J. 2018, 7, 156-160. [CrossRef]

58. Emami, S.; Rouhani, M.H.; Azadbakht, L. The effect of garlic intake on glycemic control in humans: A systematic review and meta-analysis. Prog. Nutr. 2017, 19, 10-18.

59. Gurley, B.J.; Gardner, S.F.; Hubbard, M.A.; Williams, D.K.; Gentry, W.B.; Cui, Y.; Ang, C.Y. Cytochrome P450 phenotypic ratios for predicting herb-drug interactions in humans. Clin. Pharmcol. 2002, 72, $276-287$. [CrossRef]

60. Gallicano, K.; Foster, B.; Choudhri, S. Effect of short-term administration of garlic supplements on single-dose ritonavir pharmacokinetics in healthy volunteers. Br. J. Clin. Pharmcol. 2003, 55, 199-202. [CrossRef]

61. Piscitelli, S.C.; Burstein, A.H.; Welden, N.; Gallicano, K.D.; Falloon, J. The effect of garlic supplements on the pharmacokinetics of saquinavir. Clin. Infect. Dis. 2002, 34, 234-238. [CrossRef] [PubMed]

62. Markowitz, J.S.; DeVane, C.L.; Chavin, K.D.; Taylor, R.M.; Ruan, Y.; Donovan, J.L. Effect of garlic (Allium sativum L.) supplementation on cytochrome P450 2D6 and 3A4 activity in healthy volunteers. Clin. Pharmcol. 2003, 74, 170-177. [CrossRef] 
63. Katja, B.; Albin, K. The Mechanisms Responsible for Garlic-Drug Interactions and their In Vivo Relevance. Curr. Drug Metab. 2013, 14, 90-101. [CrossRef]

64. Haghi Aminjan, H.; Abtahi, S.R.; Hazrati, E.; Chamanara, M.; Jalili, M.; Paknejad, B. Targeting of oxidative stress and inflammation through ROS/NF-kappaB pathway in phosphine-induced hepatotoxicity mitigation. Life Sci. 2019, 232, 116607. [CrossRef]

65. Phelps, S.; Harris, W.S. Garlic supplementation and lipoprotein oxidation susceptibility. Lipids 1993, 28, 475-477. [CrossRef]

66. Grune, T.; Scherat, T.; Behrend, H.; Conradi, E.; Brenke, R.; Siems, W. Influence of Allium sativum on oxidative stress status a clinical investigation. Phytomedicine 1996, 2, 205-207. [CrossRef]

67. Aalami-Harandi, R.; Karamali, M.; Asemi, Z. The favorable effects of garlic intake on metabolic profiles, hs-CRP, biomarkers of oxidative stress and pregnancy outcomes in pregnant women at risk for pre-eclampsia: Randomized, double-blind, placebo-controlled trial. J. Matern. Fetal Neonatal Med. 2015, 28, 2020-2027. [CrossRef]

68. Ziaei, S.; Hantoshzadeh, S.; Rezasoltani, P.; Lamyian, M. The effect of garlic tablet on plasma lipids and platelet aggregation in nulliparous pregnants at high risk of preeclampsia. Eur. J. Obstet. Gynecol. Reprod. Biol. 2001, 99, 201-206. [CrossRef]

69. Marchese, A.; Barbieri, R.; Sanches-Silva, A.; Daglia, M.; Nabavi, S.F.; Jafari, N.J.; Izadi, M.; Ajami, M.; Nabavi, S.M. Antifungal and antibacterial activities of allicin: A review. Trends Food Sci. Technol. 2016, 52, 49-56. [CrossRef]

70. Aydin, A.; Ersoez, G.; Tekesin, O.; Akçiçek, E.; Tuncyürek, M. Garlic oil and Helicobacter pylori infection. Am. J. Gastroenterol. 2000, 95, 563-564. [CrossRef]

71. Koçkar, C.; Oztürk, M.; Bavbek, N. Helicobacter pylori eradication with beta carotene, ascorbic acid and allicin. Acta Med. 2001, 44, 97-100. [CrossRef]

72. Zhang, X.; Yang, Y.; Gang, S.; Yang, C.; Lu, M.; Zhi, J. Berberine-, allicin- or clarithromycin- based triple therapy for the first-line treatment of Helicobacter pylori infection: An open-label, randomized trial. Gastroenterology 2014, 146, 398S. [CrossRef]

73. Mousavi, Z.B.; Mehrabian, A.; Golfakhrabadi, F.; Namjoyan, F. A clinical study of efficacy of garlic extract versus cryotherapy in the treatment of male genital wart. Dermatol. Sin. 2018, 36, 196-199. [CrossRef]

74. Josling, P. Preventing the common cold with a garlic supplement: A double-blind, placebo-controlled survey. Adv. Ther. 2001, 18, 189-193. [CrossRef]

75. Zhang, R.S. A clinical study on allicin in the prevention of thrush in newborn infants. Chin. J. Integr. Tradit. West. Med. 1992, 12, 28-29.

76. Martin, K.W.; Ernst, E. Herbal medicines for treatment of fungal infections: A systematic review of controlled clinical trials. Mycoses 2003, 47, 87-92. [CrossRef]

77. Berge, A.C.B.; Lindeque, P.; Moore, D.A.; Sischo, W.M. A clinical trial evaluating prophylactic and therapeutic antibiotic use on health and performance of preweaned calves. J. Dairy Sci. 2005, 88, 321-326. [CrossRef]

78. Donovan, D.C.; Franklin, S.T.; Chase, C.C.; Hippen, A.R. Growth and health of Holstein calves fed milk replacers supplemented with antibiotics or Enteroguard. J. Dairy Sci. 2002, 85, 947-950. [CrossRef]

(C) 2019 by the authors. Licensee MDPI, Basel, Switzerland. This article is an open access article distributed under the terms and conditions of the Creative Commons Attribution (CC BY) license (http://creativecommons.org/licenses/by/4.0/). 